\title{
Research on Reverse Technology Spillover Effect of Foreign Direct
}

\section{Investment}

\author{
Lu Ying ${ }^{1}$ \\ ${ }^{1}$ Shandong Yingcai University, Shandong, Jinan, 250104 \\ 346591653@163.com
}

\section{KEYWORDS: Direct Investment; Technology Spillover; Learning and Development}

\begin{abstract}
With the increasingly fierce global competition, foreign direct investment has become, developing countries' access to foreign advanced technology, an important means of participation in international competition, but also become a hot topic of academic research. Firstly, the theory of the mechanism of foreign direct investment in the reverse technology spillover effect of the sort, emphasizing reverse technology spillover effects need to go through two stages: in the first stage to multinational subsidiaries in the host nest innovation network, allowed to obtain advanced technical knowledge and information resources, then these subsidiaries in the second stage of technical knowledge and information resources passed back to the parent company, the parent company of digestion and absorption, transformation and re-innovation; then we will reverse technology spillover effect decomposition technique learning technologies and crowding out effect, and on the absorption capacity of the mechanism of action of reverse technology spillover effects were analyzed, and in crowding out the same premise, the ability to absorb the impact of technology learning effect by adjusting the reverse technology spillover effect.
\end{abstract}

\section{Introduction}

For enterprises in developing countries, technological progress there are two ways: First, endogenous type of technological progress, such technological advances, mainly from developing countries within the enterprise independent technological innovation; the second is foreign-source technological progress, which is refers to the use of the art of geographically uneven development, developing-country TNCs can obtain external economies from the hair country TNCs in international technology spillovers. Using foreign-source way of technological progress, enterprises in developing countries can not only significantly reduce the level of technology growth takes time, and you can save the appropriate allocation of resources, avoid duplication of research and development, detours, to achieve the level of technology at a higher starting point the extraordinary development. As the world's largest developing country, we should take the road of independent innovation under open conditions, not only to "bring in", but also "going out." Through support strong enterprises to go abroad for foreign direct investment, through the establishment of product design and development centers overseas, the use of cross-border mergers and acquisitions, technical cooperation, strategic alliances and other ways to build R \& D resources and external intelligence platform, by building their own overseas marketing network, initiative to acquire overseas advanced technology in order to accelerate the implementation of technological innovation 
internationalization strategy, develop a broader way to get technology to build their own core competencies, to participate in international competition in a more solid foundation.

\section{Reverse Technology Spillover Effect Meaning}

The so-called technology spillover effect refers to the economic behavior of the organization in the process of advanced technology owners consciously or unconsciously to its technology diffusion technology laggards. According to the regional technology spillovers occur can be divided into: international technology spillover effects, spillover effects of domestic technology, industry technology spillover effect, the industry's four forms of technology spillover effect.

The so-called reverse technology spillover effects, mainly referring to the outflow of foreign direct investment is the host country of advanced production technology, intellectual factors, information resources as a strategic objective to enhance corporate home country for the purpose of scientific and technical competence, advanced science and technology to achieve the host country horizontal diffusion of the home country, for growth, technology and the development of the home country of the ability to generate indirect economic effects unconscious.

Absorptive capacity for handling some of the usual mix of skills in technology transfer tacit knowledge, mainly by learning these skills and problem solving skills posed: is an imitation learning ability, the ability of an organization to digest external knowledge. Problem solving is an innovative capability is the ability of an organization to create new knowledge. Scholars believe that the absorptive capacity is a comprehensive concept, and the concept of absorption capacity for the first time introduced to the strategic management among enterprises, in their study, the absorption capacity of an organization is searching for knowledge and access to the external environment, and digestion and absorption, and then finally the ability to apply to the commercial production. Zhan Gao Jun of the following three concepts absorptive capacity are summarized: First, the absorption capacity performance at the individual and organizational levels, as a series of competency-based knowledge, the ultimate expression of the strength of the absorption capacity in the degree of realization of competitive advantage third knowledge, absorptive capacity is an organization from the outside environment available and digested; on; secondly, the organization's existing knowledge and past experience is the foundation of absorption capacity, absorption capacity and therefore generally has path dependence and field dependence of the characteristics and the effective integration of existing knowledge and business development activities. Zahra \& George believe conventional definition of absorptive capacity too theoretical, maneuverability is not strong is difficult to apply to the actual measurement, the absorption results of previous studies based on the scholars he proposed a definition can be measured: the absorption of an organization capacity is a set of standards and processes. Organizations to identify and access external knowledge capability, processing, understanding and the ability to analyze knowledge, knowledge digested and converted into a business model able to use the ability, the ability to use reasonable knowledge based on this set of standards and processes on.

\section{Foreign Direct Investment and Technological Development Mechanism in Enterprises Home Country}

TNCs obtained by reverse technology spillover effect of foreign direct investment route, first of all to its subsidiaries or R \& D institutions in developed nested gathering of high-end industrial technology, so that you can from the host country and local enterprises, research institutions, government agencies and other institutions to obtain access to advanced technical knowledge, 
management experience and a variety of cutting-edge information. Contact. Followed by overseas subsidiaries or research institutions can spread through various multinational inside, communication channels, these cutting-edge technical knowledge and feedback to the company's home country, the home country of these companies will gradually advanced knowledge to the production and processing sectors go, thereby improving multinational companies in the global market core competitiveness and achieve technical reverse overflow.

FDI reverse technology spillover effect need to go through two stages. In the first stage, from multinational companies through the establishment of subsidiaries in the host country, let nested in the host network to technological innovation, in order to gain advanced information and technical resources. Reference to past foreign direct investment on the reverse technology spillover effect literature, the following effects can be provided access to advanced technology and knowledge overseas subsidiaries of transnational corporation opportunity information resources.

First, follow the imitation effect. Multinational subsidiaries established abroad can learn, imitate and follow the behavior of other local companies or research institutions to improve their technological innovation. The introduction of technology, the technical imitator does not need certain economic benefits to the owners of technology spending. Multinational Subsidiary geographical proximity of the host country enterprises and research institutions, which cannot be obtained through the introduction of technology to enhance their technological innovation capability of opportunities to achieve cost savings; the second is industrial linkage effects. Multinational companies set up in the resource-rich country subsidiary technical knowledge can improve the status of overseas subsidiaries in the global industry value chain; third is talent flow effect. Subsidiaries developed countries can use to improve higher education system, high-quality technical talent pool directly recruit appropriate personnel in the host country. Direct subsidiaries employ host of high-quality R \& D personnel, and continued use of the host country's human resources through business alliances or cross-border mergers and acquisitions, etc., can enhance the technological innovation capability of overseas subsidiaries. Fourth, it is information platform effect. Gather useful technical and industrial clusters enhance the technological innovation capability of overseas subsidiaries. The reasons are the following two points: First, in an area of advanced R\&D facilities and research and development and a good environment helps to enhance research and development capabilities subsidiaries; Second, many enterprises in the geographic clustering can force a subsidiary of continuous technological innovation in order to maintain their core competitiveness. Principal product development activity is information and knowledge, knowledge and information have characteristics of public goods, Multinational subsidiaries may collect technical information for the parent company, the information including changes in the international market, the industry cutting edge of technology intelligence, industry-related technology Advances in technology and competitor strategies.

\section{Mother-enterprises Adjust Mechanism of Foreign Direct Investment Spillover Effect}

Many scholars in the study of foreign direct investment in the reverse technology spillover effect, we found there is a general two-way technology spillovers between empirical FDI in developed countries? However, foreign direct investment in developing countries the reverse technology spillover effect hypothesis testing is difficult to get the same conclusion. One of the deeper reasons is: scholars mostly from the perspective of the host country's foreign direct investment mechanism of reverse technology spillover effect, ignoring the mother country absorptive capacity of reverse technology spillover effects of positive regulation. 
From some form of view, overseas subsidiaries of transnational corporations transfer knowledge of foreign advanced technology and information resources back, it is to obtain a special channel for external technical knowledge of the parent, so the parent country absorptive capacity also plays a key role. Below we will break down the absorption capacity for the acquisition, digestion, transformation and the development of four different stages to analyze the influence of the absorption capacity of the parent company to subsidiaries passed back knowledge. When the subsidiary will acquire advanced technical knowledge in the developed markets is passed back to the home country business, business home country must first identify those technical knowledge for its own production operations play a key role in the collection and identification of the parent company subsidiaries passed back advanced technical knowledge is to determine the speed and intensity of the quality of access to technical knowledge of the key factors. After completing the technical knowledge acquisition phase, the parent company needs further technical knowledge and understanding gained digestion, which can skillfully use these external technical knowledge. Then, the parent will need to master the knowledge of foreign advanced technology and its own reserves have been accumulated technical knowledge combine to create new technologies applicable to local knowledge. Finally, the new parent company will have the technical knowledge to use in product development and production, and eventually realize their technology level, and complete the entire process of reverse technology spillover. For different companies, even if their overseas subsidiaries transferred back technical knowledge it is the same, but because of their different absorption capacity, the strength of the reverse technology spillover effect obtained will be different. Overall, we can conclude that differences in absorption capacity enterprise level led to its overseas subsidiaries in the context of the transfer back to the homogeneous technical knowledge has gained roots of different reverse technology spillover effect lies.

\section{Conclusion}

Relevant government departments in formulating policy on foreign direct investment should be more to those who already have a certain level of technical knowledge in the domestic market, has acquired a certain competitive edge of enterprises inclined to encourage them to go abroad, to accelerate the pace of Technology Sourcing FDI, improve the size of its foreign direct investment, as far as possible by way of foreign direct investment, obtain more knowledge of leading-edge technology, rapidly catching up with the rival countries. Transnational mergers and acquisitions in the technology acquisition level, enterprises should choose a suitable level of technology companies as acquisition targets, not only to the existing technical knowledge to fully understand the underlying business, the more important thing is to realize itself whether it has sufficient absorptive capacity, to achieve the state of the art for effective absorption of the target enterprise, transformation and re-innovation.

\section{Acknowledgements}

Proj: Shandong Foreign Direct Investment, Spillovers and Firm Productivity Improvement Mechanism Research Fund

Project NO. 2014ZRB019XV

\section{REFERENCE:}

[1] Adler,J. H. Absorptive Capacity: The Concept and Its Determinants [M]. Brookings Institution Washington, 1965. 
[2] Dallen,T. J. Managing the Flow of Technology: Technology Transfer and the Dissemination of Technological Information Within the R\&D Organization [M]. MIT Press Books, 1984.

[3] Walfaro, L.,Chanda, A. \& Kalemli-Ozcan, S. Et Al. FDI and Economic Growth: The Role of Local Financial Markets [J]. Journal of International Economics, 2004, 64 (1) :89-112.

[4] Eida, P. \& Kogut, B. Localization of Knowledge and The Mobility Of Engineers In Regional Networks [J]. Management Science,1999,45 (7) : 905-917.

[5] Altomonte, C. \& Pennings, E. Domestic Plant Productivity and Marginal Spillovers from Foreign Direct Investment [J]. Investment and Development Trend, 2005, 16(1): 27-28. 